\title{
Temporal changes in soil water erosion on sloping vineyards in the Ruwer- Mosel Valley. The impact of age and plantation works in young and old vines
}

\author{
Jesús Rodrigo-Comino ${ }^{1,2^{*}}$, Christine Brings ${ }^{2}$, Thomas Iserloh ${ }^{2}$, Markus C. Casper ${ }^{2}$, Manuel Seeger ${ }^{2}$, \\ José M. Senciales ${ }^{3}$, Eric C. Brevik ${ }^{4}$, José D. Ruiz-Sinoga ${ }^{1,3}$, Johannes B. Ries ${ }^{1}$ \\ ${ }^{1}$ Instituto de Geomorfología y Suelos, Department of Geography, University of Málaga, 29071, Málaga, Spain. \\ ${ }^{2}$ Department of Physical Geography, Trier University, D-54286 Trier, Germany. \\ ${ }^{3}$ Department of Geography, Málaga University, Campus of Teatinos s/n, 29071 Málaga, Spain. \\ ${ }^{4}$ Department of Natural Sciences, Dickinson State University, Dickinson, ND, USA. \\ * Corresponding author. E-mail: rodrigo-comino@uma.es
}

\begin{abstract}
It is well known that rainfall causes soil erosion in sloping German vineyards, but little is known about the effect of age of plantation on soil erosion, which is relevant to understand and design sustainable management systems. In the Ruwer-Mosel valley, young (1- to 4-years) and old (35- to 38-years after the plantation) vineyards were selected to assess soil and water losses by using two-paired Gerlach troughs over three years (2013-2015). In the young vineyard, the overland flow was $107 \mathrm{~L} \mathrm{~m}^{-1}$ and soil loss $1000 \mathrm{~g} \mathrm{~m}^{-1}$ in the year of the plantation, and decreased drastically over the two subsequent years $\left(19 \mathrm{~L} \mathrm{~m}^{-1} ; 428 \mathrm{~g} \mathrm{~m}^{-1}\right.$ ). In the old vineyard, soil (from $1081 \mathrm{~g} \mathrm{~m}^{-1}$ to $1308 \mathrm{~g} \mathrm{~m}^{-1}$ ) and water (from $67 \mathrm{~L} \mathrm{~m}^{-1}$ to $102 \mathrm{~L} \mathrm{~m}^{-1}$ ) losses were 1.2 and 1.63 times higher, respectively, than in the young vineyard.
\end{abstract}

Keywords: Soil erosion; Old vineyard; Young vineyard; Rainfall; Tillage; Ruwer-Mosel valley.

\section{INTRODUCTION}

The German viticulture region of the Mosel valley is situated close to the northern European boundary for commercial grape growing, which depends on favourable pedoclimatic conditions for winter survival and grape ripening (Ashenfelter and Storchmann, 2010). Climatic, geomorphologic and phenological characteristics are the most studied natural conditions in order to determine the quality of German vineyards (Fischer et al., 1999; Urhausen et al., 2011). The introduction of new plantations of vines and an increase in the occurrence of extreme rainfall events are contributing to soil degradation processes on German hillslope vineyards. Vegetation cover protects soil against erosion runoff generation (Martínez-Casasnovas et al., 2009; Ruiz-Colmenero et al., 2013), but also it improves soil quality (Hosseini et al., 2017; Salomé et al., 2016). This is relevant as soil can act as a natural filter for water and manage biogeochemical cycles in a world affected by global changes and searching for sustainable development (Keesstra et al., 2012). However, vineyards typically try to avoid the growth of weeds and ploughing soils to remove them is a common management strategy.

Causes of soil erosion have been investigated for the RuwerMosel valley by some authors (e.g. Hacisalihoglu, 2007; Richter, 1980; Rodrigo Comino et al., 2015a, 2015b, 2016). They concluded that: i) steep slopes $\left(15-50^{\circ}\right)$; ii) disturbance of the soil profile during plantation; iii) wheel traffic impacts due to the use of heavy machinery for tilling and ploughing; iv) high overland flow, which results in rills and ephemeral gullies; v) tillage practices in the inter-rows; and vi) high silt content, which enhances soil sealing, resulted in extremely high erosion rates.

However, little is known about soil erosion and runoff generation at the plantation scale, which is relevant to improve grape production, reduce the use of pesticides and fertilizers, and avoid losses of nutrients and water (García-Díaz et al., 2017). This knowledge will also improve understanding of the runoff generation mechanisms and the connectivity of the flows within plots, slopes and watersheds (Masselink et al., 2016; Sofia and Tarolli, 2017).

Different strategies and methods have been applied in European viticulture regions to measure, quantify and monitor soil erosion processes, including: i) small portable rainfall simulators (Prosdocimi et al., 2016; Rodrigo Comino et al., 2015a; 2015 b); ii) erosion pins and sediment traps in closed plots (Novara et al., 2011; Ruiz-Colmenero et al., 2011); iii) botanical benchmarks (Paroissien et al., 2010; Rodrigo Comino et al., 2015b, 2016); iv) remote sensing (Mathews and Jensen, 2013; Taylor et al., 2009); and v) predictive modelling (David et al., 2014). However, few researchers have focused on the temporal and seasonal changes in soil erosion at different vine ages.

The main goal of this study was to assess the role of water in soil erosion processes on two paired plots with vineyards of different ages since plantation (1- to 4- and 35- to 38-year old plots, called here young and old plantations, respectively) over three years to understand the seasonal and temporal changes in soil erosion. This strategy will inform us about the effect of plantation on the total soil erosion over the life-span of a vineyard.

\section{MATERIALS AND METHODS Study area}

The studied area is located in the village of Waldrach ( $\mathrm{Ru}-$ wer-Mosel Valley, Rhineland-Palatinate, Germany; $49.7418 \mathrm{~N}$; $6.7524 \mathrm{E}$, Figure 1). The mean annual rainfall is $765 \mathrm{~mm}$, and during the research period, the annual rainfalls were $902 \mathrm{~mm}$ (2013), $660 \mathrm{~mm}$ (2014) and $524 \mathrm{~mm}$ (2015). The highest values are concentrated in the summer months (65-72 mm per month) and the lowest values of monthly precipitation are between February and April (50-60 mm per month). The average annual temperature is $9.3^{\circ} \mathrm{C}$, with average maximum values from June to August $\left(16.2-17.6^{\circ} \mathrm{C}\right)$ and minimum values from December to January $\left(1.5-2.3^{\circ} \mathrm{C}\right)$. The old and young vineyards are situated on a single hillslope with an altitude from 200 to $300 \mathrm{~m}$ a.s.l. and slopes from $15^{\circ}$ to $30^{\circ}$. The length of both plots ranged 

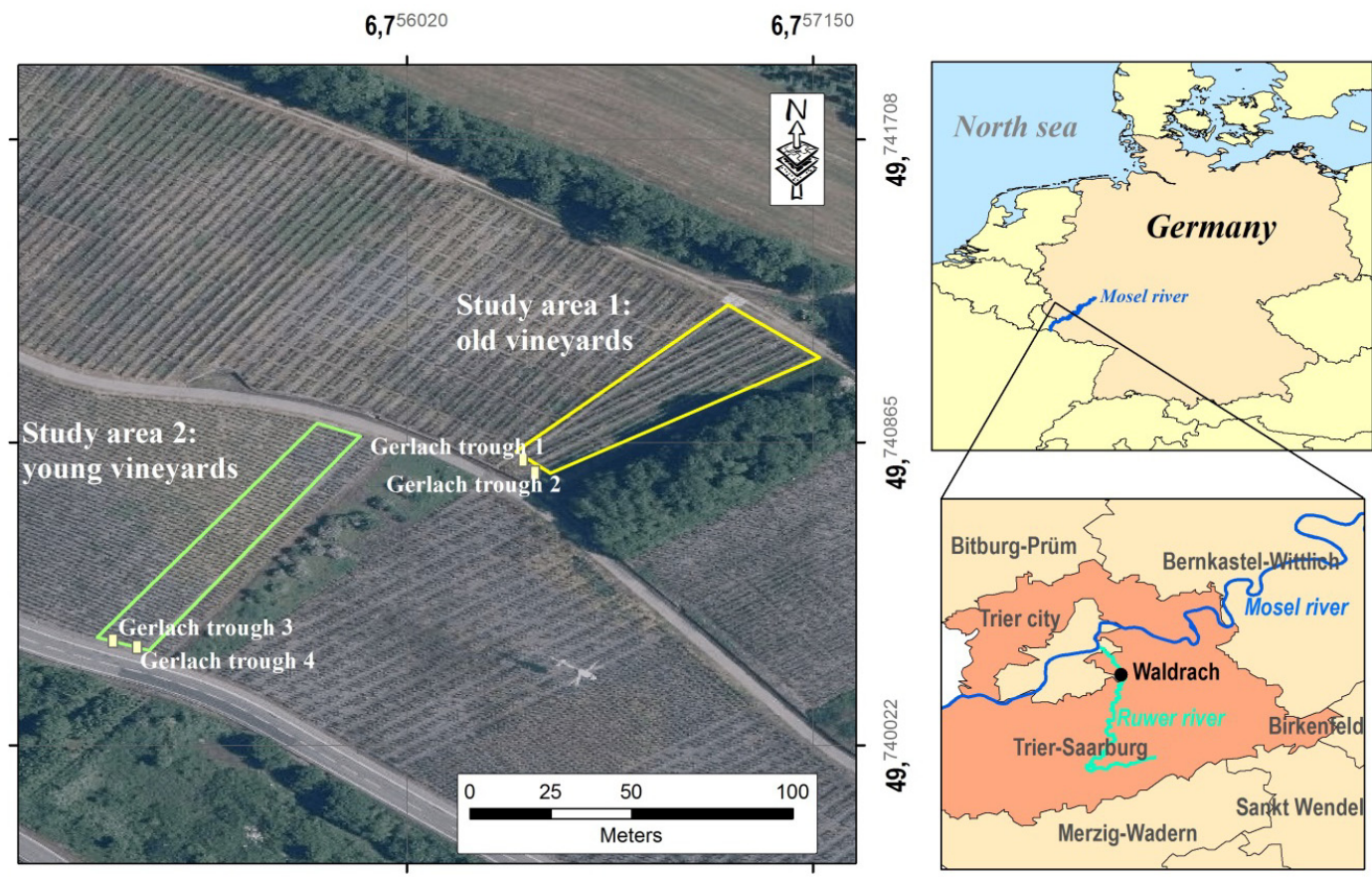

Fig. 1. Study area in the Ruwer-Mosel Valley.

Table 1. Soil analysis of physical and chemical properties.

\begin{tabular}{lcc}
\hline & Old vineyards & Young vineyards \\
\hline Gravel (\%) & $37.9 \pm 4.8$ & $59.7 \pm 5.1$ \\
\hline Fine material (\%) & $62.1 \pm 4.8$ & $40.3 \pm 5.1$ \\
\hline Sand (\%) & $26 \pm 3.1$ & $26.8 \pm 6.9$ \\
\hline Silt (\%) & $64.7 \pm 2.8$ & $64.3 \pm 5.8$ \\
\hline Clay (\%) & $9.3 \pm 1.4$ & $8.9 \pm 1.3$ \\
\hline TOC (\%) & $7.9 \pm 3.6$ & $6.1 \pm 3.2$ \\
\hline $\mathrm{CaCO}_{3}(\%)$ & $0.9 \pm 0.3$ & $1.2 \pm 0.3$ \\
\hline $\mathrm{EC}\left(\mathrm{dS} \mathrm{m}^{-1}\right)$ & $0.3 \pm 0.2$ & $0.4 \pm 0.2$ \\
\hline $\mathrm{pH}\left(\mathrm{H}_{2} \mathrm{O}\right)$ & $7.2 \pm 0.2$ & $6.5 \pm 0.2$ \\
\hline $\mathrm{pH}(\mathrm{KCl})$ & $6.4 \pm 0.2$ & $6.5 \pm 0.3$ \\
\hline Dif. & $0.9 \pm 0.1$ & $0 \pm 0.1$ \\
\hline SWC $(\% ; \mathrm{FC})$ & $27.7 \pm 4.5$ & $28.8 \pm 3.4$ \\
\hline SWC $(\% \mathrm{WP})$ & $12.3 \pm 2.4$ & $10.5 \pm 1.5$ \\
\hline
\end{tabular}

between 60 and 70 meters. Soils are classified as leptic-humic Regosols (IUSS Working Group WRB, 2014). Physical and chemical soil properties are summarized in Table 1. Information about soil analysis procedures were explained in detail in Rodrigo Comino et al. (2016).

The highest stone content was observed in the young vineyard $(59.7 \pm 5.1 \%)$. In the old vineyard stone content was $37.9 \pm 4.8 \%$. Silt was the most common particle size at the study site with an average of $64.7 \%$ in the old vineyard and $64.3 \%$ in the young one. The sand content averaged $26 \%$ in the old plot and $26.8 \%$ in the young one. Clay particles arranged from $8.9 \%$ (young vineyard) to $9.3 \%$ (old vineyard). Soil textures were silty loam in both plots. High soil water content at field capacity was documented for both areas, being close to $30 \%$. At the wilting point, values decreased to $12.3 \%$ in the old vineyard and $10.5 \%$ in the young one. Total organic carbon was higher in the old vineyard $(7.9 \%)$ than in the young one $(6.1 \%)$. Carbonates content was low in both studied areas (from $0.9 \%$ to $1.2 \%$ ). Electrical conductivity was considered extremely low, with values from $0.3 \mathrm{dS} \mathrm{m}^{-1}$ to $0.4 \mathrm{dS} \mathrm{m}^{-1}$. Values of soil $\mathrm{pH}$ in the old vineyard were higher (7.2 with water solution and 6.4 in $\mathrm{KCl})$ than in the young one (6.4 and 6.5 , respectively). There- fore, no soil acidification trends were noted in the old vineyard. Even if the differences had been greater than 1, no soil acidification trend would have been noted in the old vineyard because the old vineyard $\mathrm{pH}$ was higher (more basic). On the other, a slight acidification trend was observed in the young vineyard.

Similar traditional soil tillage and vine training systems were used in both vineyards. The grape variety is Riesling and the yearly soil management consists of: i) a mechanical tilling of the top layer $(\approx 20 \mathrm{~cm})$ before and after grape harvesting (spring and early autumn); ii) the use of mulch and grass covers, which range from about $20 \mathrm{~cm}$ along the inter-rows and under vines to between $10-35 \mathrm{~cm}$ of height; iii) the use of vine training systems composed of a plantation framework about $0.9 \mathrm{~m} \mathrm{x} 1.0 \mathrm{~m}$; iv) redistributing a soil cover of slates to protect the surface against cold temperatures; and, v) the application of sprays during spring and summer by helicopter.

\section{Soil loss, runoff and sediment concentration measures using Gerlach troughs}

Gerlach troughs were built, installed and utilized as sediment collectors (Gerlach, 1967). Four sediment collectors with a width of $150 \mathrm{~cm}$ were placed in the inter-rows and part of the rows (Fig. 2). Amounts of soil loss, surface flow and sediment concentration were calculated in $\mathrm{g}, \mathrm{L}$ and $\mathrm{g} \mathrm{L}^{-1}$, respectively. The open soil erosion plots gave information about the soil $(\mathrm{g})$ and water losses (L) but the contributing area is uncertain. This is why the soil erosion rates or overland flow are shown in $\mathrm{g} \mathrm{m}^{-1}$ and $\mathrm{L} \mathrm{m}^{-1}$, respectively.

Over a period of three years (2013-2015), two Gerlach troughs were located at the bottom of each studied crop. They were equipped with a slanted front edge to prevent scouring or undercutting of the trough. Additionally, all of them were connected to collecting tanks $(200 \mathrm{~L})$ to be prepared for extreme rainfall events, which can exceed the total storage capacity of the collector ( $30 \mathrm{~L}$ up to the spillway). Two Hellmann rain gauges were placed close to the Gerlach troughs in both vineyards to measure rainfall amounts from each natural event. 


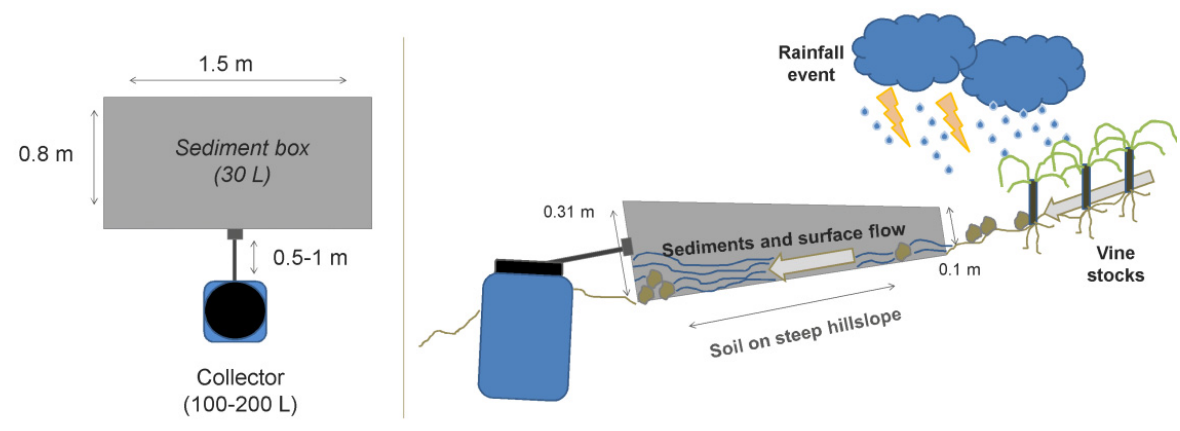

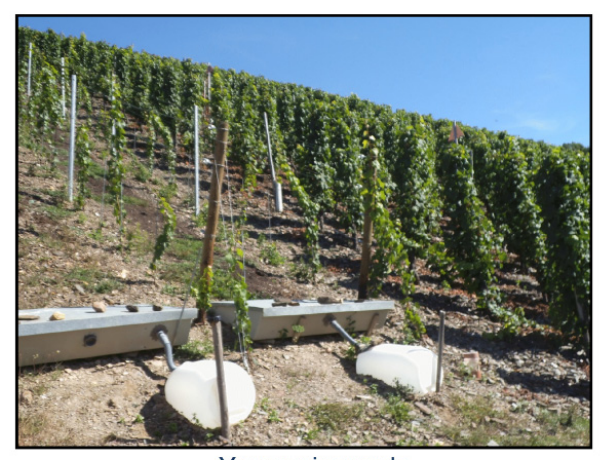

Young vineyards

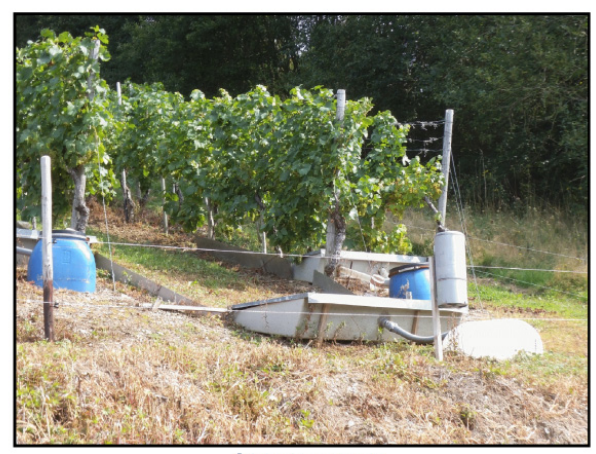

Old vineyards

Fig. 2. Gerlach troughs in old and young vineyards.

The maintenance of the equipment and sampling were performed every one to three weeks. Samples were used to determine overland flow and sediment concentration, and from that to calculate soil erosion rates. All single events were summed up as annual (2013, 2014 and 2015) and seasonal intervals (December-February, March-May, June-August and September-November).

\section{Statistical analysis}

The Spearman rank coefficient was calculated to observe the statistical significance between soil erosion and rainfall events or human interventions, which did not show parametric distributions. Furthermore, to assess soil erosion variability, an index for the replicated erosion plots proposed by Nearing et al. (1999) was applied (Eq. 1):

$R_{\text {diff }}=\frac{M 2-M 1}{M 2+M 1}$

where M1 and M2 are paired values of every soil loss and overland flow quantifications from two replicate plots. These values can oscillate between 0 and 1, when M2 is equal to M1, no relative differences exist among the paired values.

Finally, a Mann-Whitney Rank Sum Test was applied to test differences between values using SigmaPlot 13 (Systat Software, Inc.), after observing non-normal distribution of the data.

\section{RESULTS}

All registered events obtained by using the four Gerlach troughs were compared by histogram analysis. A high variability of the distribution was observed (Fig. 3). The frequency distributions showed a majority of rainfall events did not lead to soil loss and overland flow. However, both distributions showed large differences in their extreme values. In the old vineyard, Gerlach trough number 2 recorded the highest variability and differences with sediment collector number 1 , show- ing more events with greater than $400 \mathrm{~g} \mathrm{~m}^{-1}$ of soil loss and $300 \mathrm{~g} \mathrm{~L}^{-1}$ of sediment concentration. In the young vineyard, several differences were obtained between the two-paired Gerlach troughs for events with an overland flow greater than $9 \mathrm{~L} \mathrm{~m}^{-1}$ and more than $75 \mathrm{~g} \mathrm{~L}^{-1}$.

Seventy-five rainfall events during the three study years (2013-2015) are summarized in Table 2 and Figure 4. The highest total rainfall $(902 \mathrm{~mm})$ was recorded in 2013 and then the annual precipitation decreased by $26.8 \%$ (2014) and $41.9 \%$ (2015) relative to 2013. The highest average overland flow and soil loss $\left(107.4 \mathrm{~L} \mathrm{~m}^{-1} ; 1000.4 \mathrm{~g} \mathrm{~m}^{-1}\right)$ were recorded during 2013 for the young vineyard. In the following two years (2014 and 2015), parallel with the decreased rainfall amount, these values decreased by $82.3 \%$ and $57.2 \%$, respectively. However, the sediment concentration increased by $215 \%$ from 2013 $\left(9.3 \mathrm{~g} \mathrm{~L}^{-1}\right)$ to $2015\left(29.3 \mathrm{~g} \mathrm{~L}^{-1}\right)$. The data for the old vineyard showed an increase in the overland flow of about $4 \%$ $\left(1.7 \mathrm{~L} \mathrm{~m}^{-1}\right)$ and a soil loss of about $8.9 \%\left(95.7 \mathrm{~g} \mathrm{~m}^{-1}\right)$. The highest results were recorded in 2014 with $101.6 \mathrm{~L} \mathrm{~m}^{-1}$ for overland flow and $1308.1 \mathrm{~g} \mathrm{~m}^{-1}$ for soil loss. However, the increased sediment concentration was similar to the young vineyard for the same period (2013-2015): 194.3\%.

Looking at the seasonal pattern (Table 3), the highest overland flow was registered in the young vineyard from December to February $\left(63.5 \mathrm{~L} \mathrm{~m}^{-1}\right)$ and in the old vineyard between September and November $\left(104.7 \mathrm{~L} \mathrm{~m}^{-1}\right)$, which coincided with the grape harvesting period (October-November). For the young vineyard, the lowest values were found in spring (March-May) at $34.8 \mathrm{~L} \mathrm{~m}^{-1}$ and $26 \mathrm{~L} \mathrm{~m}^{-1}$, respectively. From June to August, soil loss values showed the highest rates $\left(1013.1 \mathrm{~g} \mathrm{~m}^{-1}\right)$ at the end of the soil tillage practices and before the grape harvesting period. For the old vineyard, the highest amounts were recorded in autumn $\left(1053 \mathrm{~g} \mathrm{~m}^{-1}\right)$ and spring (March-May, $1293.2 \mathrm{~g} \mathrm{~m}^{-1}$ ).

Taking both plots into account, the highest sediment concentrations coincided with the lowest overland flow and the highest soil loss rates. In the young vineyard, the results reached $24.5 \mathrm{~g} \mathrm{~L}^{-1}$ (June, July and August) and in the old vineyard $110.2 \mathrm{~g} \mathrm{~L}^{-1}$ (March, April and May). These times coincided 
The impact of age and plantation works in young and old vines (Ruwer-Mosel valley, Germany)
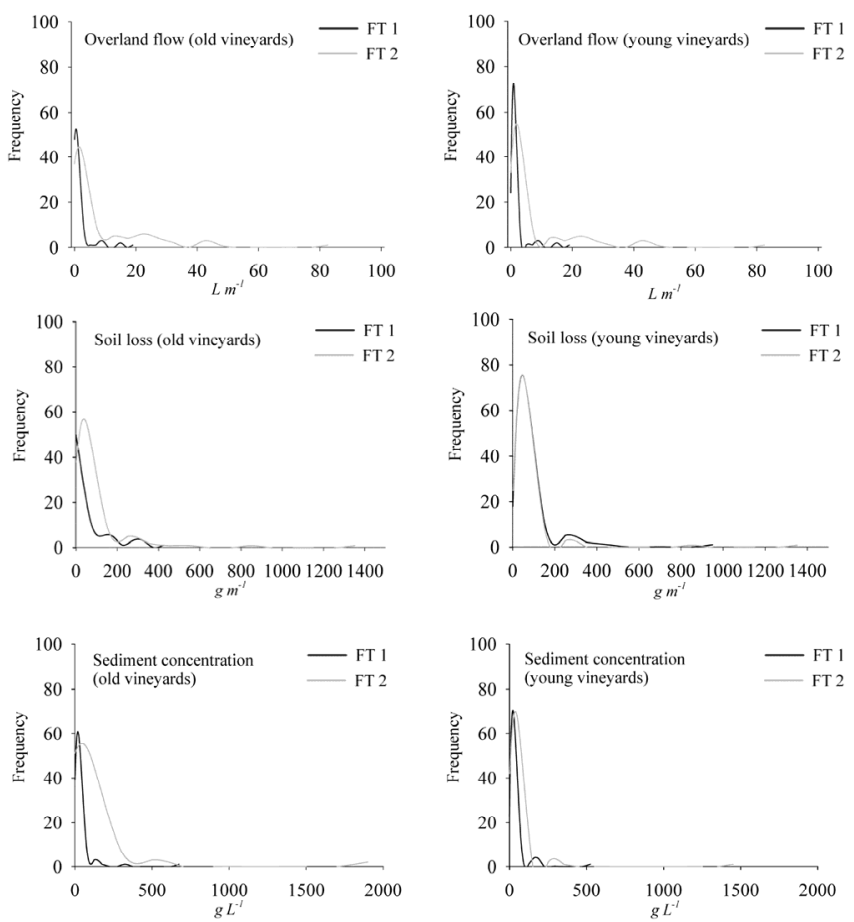

Table 2.Total annual average overland flow, soil loss and sediment concentration between 2013 and 2015 .

\begin{tabular}{lccc} 
& Year & Young vineyard & Old vineyard \\
\hline \multirow{3}{*}{ Overland flow $\left(\mathrm{L} \mathrm{m}^{-1}\right)$} & 2013 & $107.4(0.6)$ & $67.0(56.1)$ \\
\cline { 2 - 4 } & 2014 & $61.4(6.7)$ & $101.6(117.5)$ \\
\cline { 2 - 4 } & 2015 & $18.9(11.9)$ & $69.7(89.8)$ \\
\hline \multirow{3}{*}{ Soil loss $\left(\mathrm{g} \mathrm{m}^{-1}\right)$} & 2013 & $1000.4(1078.7)$ & $1081(380.7)$ \\
\cline { 2 - 4 } & 2014 & $752.9(199.3)$ & $1308.1(529.8)$ \\
\cline { 2 - 4 } $\begin{array}{l}\text { Sediment concentration } \\
\left(\mathrm{g} \mathrm{L}^{-1}\right)\end{array}$ & 2015 & $428.2(50.6)$ & $1176.7(677.1)$ \\
\cline { 2 - 4 } & 2013 & $9.3(10.1)$ & $21.2(12.1)$ \\
\hline \multirow{2}{*}{ Rainfall depth (mm yr } & $-12.5(4.6)$ & $29.7(29.1)$ \\
\cline { 2 - 4 } & 2014 & \multicolumn{3}{c}{902} \\
\cline { 2 - 4 } & 2015 & \multicolumn{3}{c}{560} \\
\hline
\end{tabular}

(): standard deviation.

Table 3. Total seasonal average overland flow, soil loss and sediment concentration between 2013 and 2015.

\begin{tabular}{|c|c|c|c|}
\hline & Season & Young vineyard & Old vineyard \\
\hline \multirow{4}{*}{ Overland flow $\left(\mathrm{L} \mathrm{m}^{-1}\right)$} & D-J-F & $63.5(13.4)$ & $41.4(37)$ \\
\hline & M-A-M & $34.8(10.9)$ & $26.0(29.6)$ \\
\hline & $\mathrm{J} J-A$ & $43.5(4.9)$ & $66.3(85.4)$ \\
\hline & S-O-N & $45.9(33.8)$ & $104.7(111.3)$ \\
\hline \multirow{4}{*}{ Soil loss $\left(\mathrm{g} \mathrm{m}^{-1}\right)$} & D-J-F & $391.5(97.7)$ & $445.0(262.8)$ \\
\hline & M-A-M & $397.5(112.8)$ & $1293.2(511.6)$ \\
\hline & J-J-A & $1013.1(829.1)$ & $774.6(535.4)$ \\
\hline & S-O-N & $382.7(388)$ & $1053.0(277.7)$ \\
\hline \multirow{4}{*}{$\begin{array}{l}\text { Sediment concentration } \\
\left(\mathrm{g} \mathrm{L}^{-1}\right)\end{array}$} & D-J-F & $6.1(0.2)$ & $13.2(5.5)$ \\
\hline & M-A-M & $12.6(7.2)$ & $110.2(106)$ \\
\hline & J-J-A & $24.5(21.8)$ & $38.0(40.9)$ \\
\hline & S-O-N & $7.2(3.2)$ & $19.9(18.5)$ \\
\hline \multirow{4}{*}{$\begin{array}{l}\text { Rainfall depth (mm) } \\
\text { 2013-2015 }\end{array}$} & D-J-F & \multicolumn{2}{|c|}{481} \\
\hline & M-A-M & \multicolumn{2}{|c|}{496} \\
\hline & $\mathrm{J}-\mathrm{J}-\mathrm{A}$ & \multicolumn{2}{|c|}{552} \\
\hline & S-O-N & \multicolumn{2}{|c|}{556} \\
\hline
\end{tabular}

*D-J-F: between December, January and February; M-A-M: between March, April and May; J-J-A: between June, July and August; S-O-N: between September, October and November; (): standard deviation.

Table 4. Spearman's rank correlation coefficient between overland flow, soil loss, sediment concentration and rainfall depth in diverse seasons for the old and young vineyards.

\begin{tabular}{cccc|ccccc}
\hline \multicolumn{4}{c}{ Young vineyards } & \multicolumn{5}{c}{ Old vineyards } \\
D-J-F & OF & SL & SC & D-J-F & OF & SL & SC \\
\hline OF & & & & OF & & & \\
SL & 0.070 & & & SL & 0.431 & & \\
SC & -0.409 & $0.722^{* *}$ & & SC & 0.075 & $0.812^{* *}$ & \\
mm & -0.079 & 0.197 & 0.330 & mm & $0.707^{* *}$ & 0.375 & 0.160 \\
\hline M-A-M & OF & SL & SC & M-A-M & OF & SL & SC \\
\hline OF & & & & OF & & & \\
SL & $0.646^{* *}$ & & & SL & $0.65^{* *}$ & & \\
SC & $0.531^{* *}$ & $0.608^{* *}$ & & SC & $0.739^{* *}$ & $0.887^{* *}$ & \\
mm & $0.513^{* *}$ & 0.111 & 0.192 & mm & $0.754^{* *}$ & 0.368 & $0.519^{*}$ \\
\hline J-J-A & OF & SL & SC & J-J-A & OF & SL & SC \\
\hline OF & & & & OF & & & \\
SL & -0.083 & & & SL & 0.319 & & \\
SC & -0.132 & $0.754^{* *}$ & & SC & 0.233 & $0.833^{* *}$ & \\
mm & $0.824^{* *}$ & -0.080 & -0.075 & mm & $0.707^{* *}$ & 0.131 & 0.095 \\
\hline S-O-N & OF & SL & SC & S-O-N & OF & SL & SC \\
\hline OF & & & & OF & & & \\
SL & 0.374 & & & SL & $0.863^{* *}$ & & \\
SC & -0.275 & 0.5 & & SC & 0.511 & $0.632^{*}$ & \\
mm & $0.626^{*}$ & 0.324 & 0.005 & mm & 0.451 & 0.396 & 0.033 \\
\hline
\end{tabular}

$*: \mathrm{p}<0.05 ; * * \mathrm{p}<0.01 ;$ OF: overland flow $\left(\mathrm{L} \mathrm{m}^{-1}\right)$; SL: soil loss $\left(\mathrm{g} \mathrm{m}^{-1}\right)$; $\mathrm{SC}$ : sediment concentration $\left(\mathrm{g} \mathrm{L}^{-1}\right) ; \mathrm{mm}$ : rainfall depth in each season. 


\section{DISCUSSION}

This research aimed to contribute valuable information on viticulture regions and their soil erosion processes. In both vineyards, similarities were found such as compaction, evidence in the sub-surface layers caused by ploughing and tilling. However, several pedological and hydrological differences were also observed. The young vineyard showed higher slopes $\left(3^{\circ}\right.$ and $5^{\circ}$ more) and gravel content than the old one. These micro-topographical changes and the schistosity enhance the weathering of the slates. The rock fragments mainly form a laminar morphology and high angularity, offering greater resistance to sediment movement along parts of the slope (Battany and Grismer, 2000; Fox et al., 1997). Both plots had silty loam soil texture, but the young vineyard showed higher sand content and the old vineyard had a higher fraction of clay (from the backslope to the bottom). The higher soil water content (at field capacity and wilting point) in the old vineyard was directly related to these textural differences, where the soils had a greater water retention capacity that reduced the possibility of overland flow generation and, therefore, soil loss (Rodrigo Comino et al., 2015a). There was also evidence of natural sieving of the silt particles caused by the raindrop impact (Hänsel et al., 2016; Marzen et al., 2015). The kinetic energy applied to aggregates with elevated silt values is more likely to enhance the transport and disaggregation of the fine particles down slope only during low rainfall intensities (Ramos et al., 2000).

Another main factor influencing erosion and runoff was the initial disturbance of the soil profile during the preparation and levelling practices of the plantation. This activity modified the soil structure and increased the stone fraction, enhancing runoff generation after extreme rainfall events or soil tillage (Biddoccu et al., 2016; Ramos and Martínez-Casasnovas, 2006), but only during the first year. Similar impacts of tillage or herbicides that enhanced runoff and erosion in comparison with catch crops, straw mulches, or geotextiles have been observed in studies (Prosdocimi et al., 2016). In the young vineyard, we observed that a decrease in the yearly rainfall amount and the stabilisation of the topsoil layers (structure and non-embedded stoniness) lead to a drastic decrease in the overland flow and soil loss from 2013 (year of plantation) to 2015.

After analysing soil erosion processes by combining seasonal rainfall amounts and soil tillage practice observations, two different hydrological dynamics were found (Fig. 5). Before harvesting (March-October), soil loss was activated without rainfall due to: i) soil tillage practices, which enhanced soil compaction and reduced the permeability; and ii) the low soil moisture values favoured the disaggregation of the fine particles. As a result, the highest sediment concentration values showed low statistical significance with the rainfall events. This process was more intense in the old vineyard than in the young one, where the activities of the farmers were greater during the time and thus had more influence on hydrologic processes. Quinn et al. (1980) found that human trampling is a key factor determining soil erosion too. However, there is a lack of information about the impact of human traffic on vineyard soil processes. The majority of studies have investigated animal trampling (Pulido-Fernández et al., 2013) or recreational activities (Tibor and Brevik, 2013; Williams and Brevik, 2010), showing negative effects on soil properties such as compaction (Godefroid and Koedam, 2004), but have not investigated agricultural lands. There is a need to investigate how farmer trampling modifies soil compaction and aggregate stability in vineyards to develop plans and strategies to avoid its impact (Rodrigo Comino et al., 2016). The same dynamic was also confirmed by

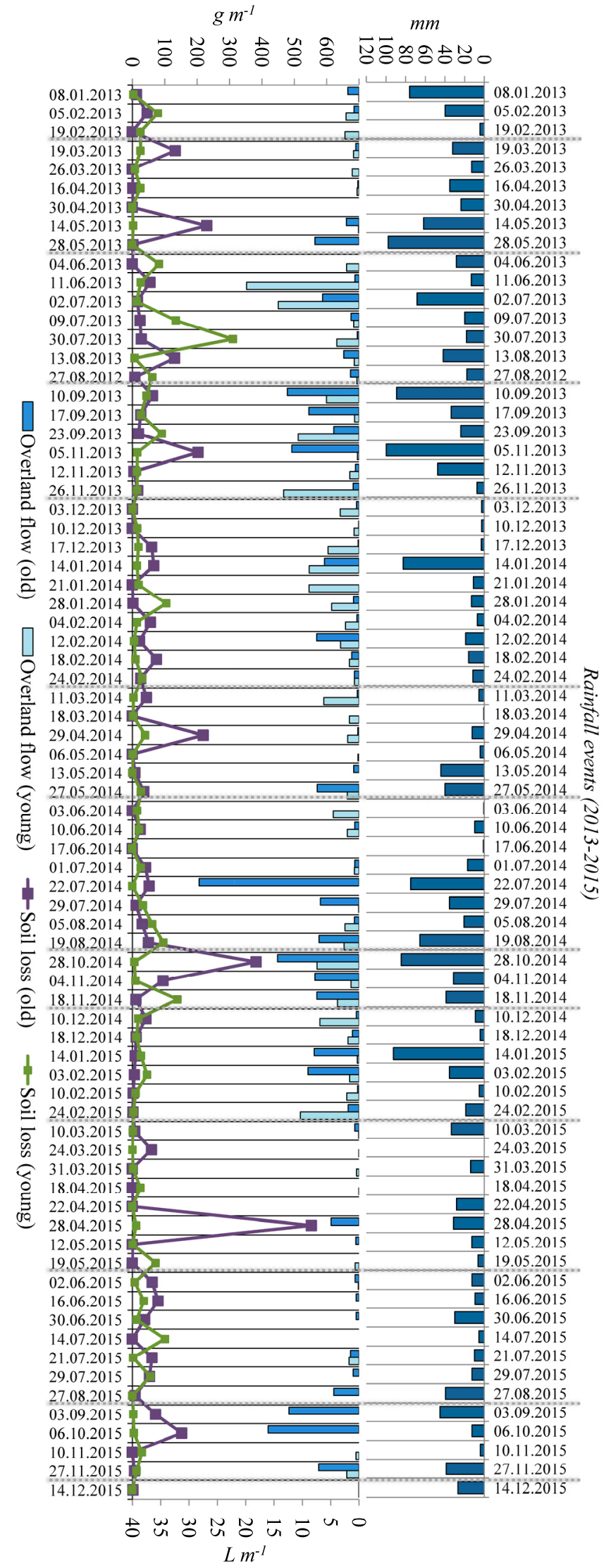

Fig. 4. Total rainfall events, overland flow and soil loss, in old and young vineyards.

Richter, (1980), Hacisihloglu (2007) and Rodrigo Comino et al., (2015a; 2015b) in the Ruwer-Mosel Valley. On the contrary, after harvesting we observed that soil compaction decreased 
The impact of age and plantation works in young and old vines (Ruwer-Mosel valley, Germany)

Table 5. Relative similarities between the two-paired erosion plots.

\begin{tabular}{lcccc}
\hline Type of vineyards & \multicolumn{2}{c}{ Old vineyards } & \multicolumn{2}{c}{ Young vineyard } \\
\hline Soil erosion parameters & Overland flow & Soil loss & Overland flow & Soil loss \\
\hline $\mathrm{R}_{\text {diff }}($ Nearing et al., 1999) & 0.78 & 0.31 & 0.01 \\
\hline Mann-Whitney Rank Sum Test & $\mathrm{P}=0.001^{*}$ & $\mathrm{P}=0.042^{*}$ & 0.4 & $\mathrm{P}=0.064$ \\
\hline
\end{tabular}

*: There is a statistically significant difference.

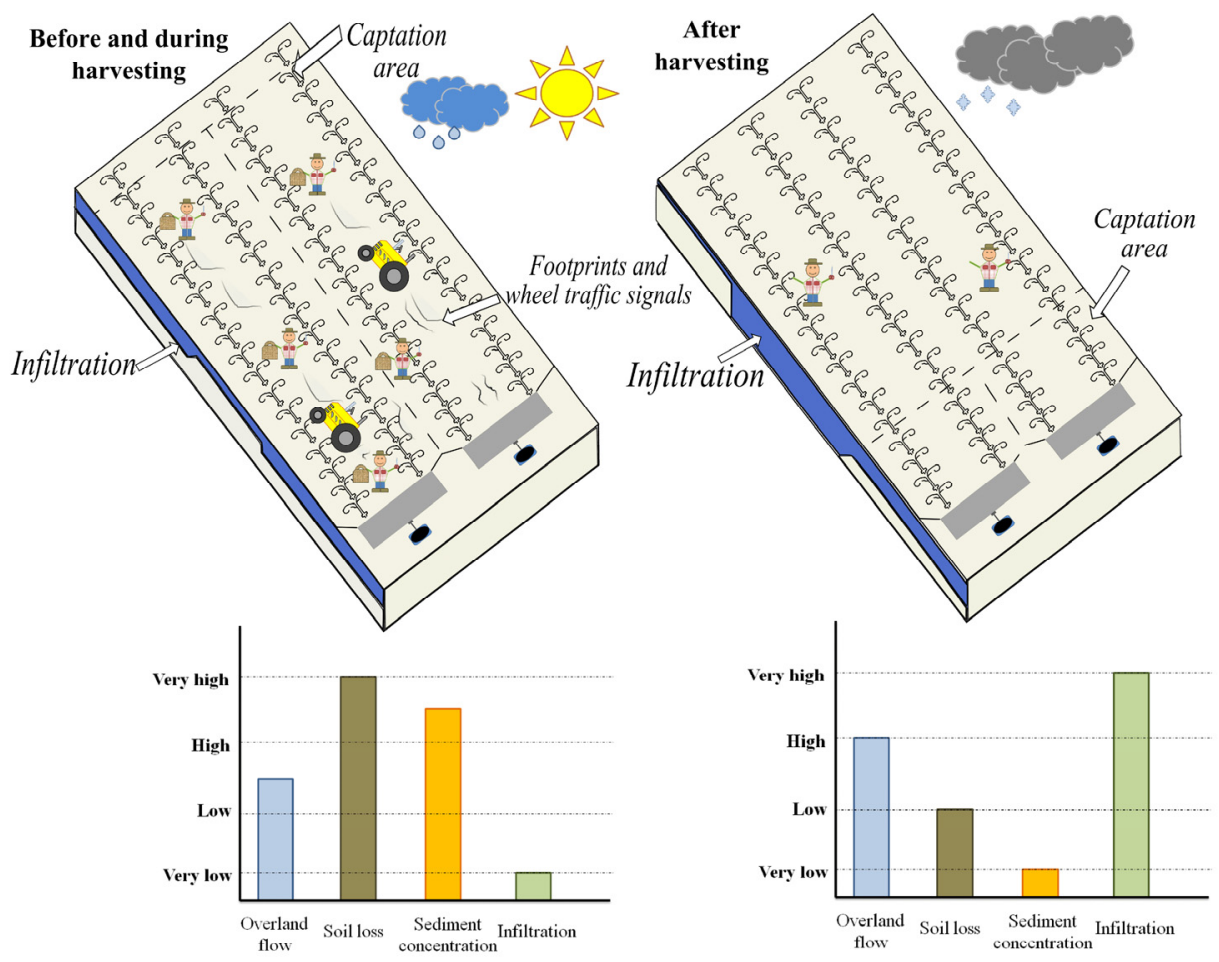

Fig. 5. Sketch of the spatiotemporal variability of hydrological and geomorphological processes due to rainfall events and soil tillage practices.

and permeability increased (greater in the young vineyard than in the old one). Moreover, soil moisture increased enhancing the aggregation of the fine particles. Rainfall depth also decreased and while overland flow values showed some peaks, soil loss rates decreased. Therefore, corresponding sediment concentration values were lower. Lasanta (1985), during a study in La Rioja (Spain), found evidence that supported the idea that a frozen surface also enhances hydric fluxes and, for instance, decreases infiltration in vineyards.

Mechanisms of sub-surface flow can also play an important role in the main hydrological dynamic (Hewlett and Hibbert, 1967; Nasri et al., 2015). Rodrigo Comino et al. (2015a; $2015 b$ ), using a small portable rainfall simulator, confirmed high infiltration coefficients (near 100\%) in this region and small peaks in runoff coefficient during this period with negligible suspended sediment loads values. The alteration of the natural hydrological dynamics due to soil tillage, especially in the young vineyard, can imply several problems regarding solute transport, nutrients and soil losses, landslides due to piping processes, formation of rills and ephemeral gullies, degradation of roots, and decreased productivity (Biddoccu et al., 2013; Bogunović et al., 2016; Hosseini et al., 2017).

In the future, it would be interesting to pay more attention to the intra-plot differences in soil erosion processes in vineyards due to trampling effect, assumed sub-surface flow, tillage erosion, and compaction by machinery. Our statistical analysis showed an important modification of the natural overland flow and soil loss patterns (extreme rainfall events should generate more erosion), but the variability at the intra-plot scale was very high which made forecasting difficult. Moreover, these spatio-temporal variations could hinder possible land management plans for larger scales (Chaplot and Poesen, 2012).

To achieve this goal, possibly other techniques such as SfM or Lidar data (Hänsel et al., 2016), soil simulation functions with decision networks (Mohajerani et al., 2017), carbon isotopic signatures (Novara et al., 2015), or remote sensing (Taylor et al., 2009) could be useful to compare areas of varying viticultural ages, different soil properties, and different land use managements. Moreover, the use of rainfall simulators is highly recommended to study spatial variability in soil erosion, as reported by different authors in agricultural and forest soils around the world (Iserloh et al., 2012; Ries et al., 2009). This is because the use of controlled rainfall allows researchers to avoid the spatial and temporal variability found in natural rainfall (Katebikord et al., 2017; Sadeghi et al., 2017). Therefore, researchers are able to gain a more accurate understanding of the impact of human activities, the role of vegetation and plant species composition and soil management (Berendse et al., 2015; Salomé et al., 2016) and sediment modelling at catchment area (Bertalan et al., 2016) on soil erosion and runoff.

\section{CONCLUSIONS}

Soil erosion monitoring between 2013 and 2015 showed that the highest recorded overland flow $\left(107 \mathrm{~L} \mathrm{~m}^{-1}\right)$ and soil loss $\left(1000 \mathrm{~g} \mathrm{~m}^{-1}\right)$ were experienced during the first year of plantation. Soil erosion in the old vineyard was more related to rainfall properties, tillage management, and harvest activities. We 
concluded that agriculture soil management by heavy machinery and soil levelling during the plantation are the main causes of soil erosion, and once the plantation is established, soil erosion is mainly controlled by trampling effects and compaction by heavy machinery during harvest.

Acknowledgements. We acknowledge the Weinbauverband Moseland, the winery Gebrüder Steffes (Waldrach) and the winery Langguth (Traben-Trarbach) for providing access to the studied areas. We also acknowledge laboratory and field technicians (GSoilLab) M. Pedraza and R. Rojas from Málaga and R. Bielen and Y. Hausener from Trier. Furthermore, we thank Cristian Cuevas Zamora for English corrections. Jesús Rodrigo Comino thanks the Ministerio de Educación, Cultura y Deporte de España for the scholarship grant award (FPU15/01499).

\section{REFERENCES}

Ashenfelter, O., Storchmann, K., 2010. Using hedonic models of solar radiation and weather to assess the economic effect of climate change: the case of Mosel valley vineyards. Rev. Econ. Stat., 92, 333-349.

Battany, M.C., Grismer, M.E., 2000. Rainfall runoff and erosion in Napa Valley vineyards: effects of slope, cover and surface roughness. Hydrological Processes, 14, 7, 1289-1304. DOI: $\quad 10.1002 /($ SICI)1099-1085(200005)14:7<1289::AIDHYP43>3.0.CO;2-R.

Berendse, F., van Ruijven, J., Jongejans, E., Keesstra, S., 2015. Loss of plant species diversity reduces soil erosion resistance. Ecosystems, 18, 5, 881-888. DOI: 10.1007/s10021015-9869-6.

Bertalan, L., Tóth, C.A., Szabó, G., Nagy, G., Kuda, F., Szabó, S., 2016. Confirmation of a theory: reconstruction of an alluvial plain development in a flume experiment. Erdkunde, 70, 271-285. DOI: 10.3112/erdkunde.2016.03.05.

Biddoccu, M., Ferraris, S., Cavallo, E., Opsi, F., Previati, M., Canone, D., 2013. Hillslope vineyard rainfall-runoff measurements in relation to soil infiltration and water content. Procedia Environ. Sci., 19, 351-360. DOI: 10.1016/j.proenv.2013.06.040.

Biddoccu, M., Ferraris, S., Opsi, F., Cavallo, E., 2016. Longterm monitoring of soil management effects on runoff and soil erosion in sloping vineyards in Alto Monferrato (NorthWest Italy). Soil Tillage Res., 155, 176-189. DOI: 10.1016/j.still.2015.07.005.

Bogunović, I., Kisić, I., Maletić, E., Perčin, A., Matošić, S., Roškar, L., 2016. Soil compaction in vineyards of different ages in Pannonian Croatia. Part I. Influence of machinery traffic and soil management on compaction of individual horizons. J. Cent. Eur. Agric., 17. DOI:10.5513/jcea.v17i2.4294.

Chaplot, V., Poesen, J., 2012. Sediment, soil organic carbon and runoff delivery at various spatial scales. Catena, 88, 4656. DOI: 10.1016/j.catena.2011.09.004.

David, M., Follain, S., Ciampalini, R., Le Bissonnais, Y., Couturier, A., Walter, C., 2014. Simulation of medium-term soil redistributions for different land use and landscape design scenarios within a vineyard landscape in Mediterranean France. Geomorphology, 214, 10-21. DOI: 10.1016/j.geomorph.2014.03.016.

Fischer, U., Roth, D., Christmann, M., 1999. The impact of geographic origin, vintage and wine estate on sensory properties of Vitis vinifera cv. Riesling wines. Food Qual. Prefer., 10, 281-288. DOI: 10.1016/S0950-3293(99)00008-7.

Fox, D.M., Bryan, R.B., Price, A.G., 1997. The influence of slope angle on final infiltration rate for interrill conditions.
Geoderma, $\quad 80, \quad 181-194 . \quad$ DOI: $\quad 10.1016 /$ S00167061(97)00075-X.

García-Díaz, A., Bienes, R., Sastre, B., Novara, A., Gristina, L., Cerdà, A., 2017. Nitrogen losses in vineyards under different types of soil groundcover. A field runoff simulator approach in central Spain. Agric Ecosyst Environ, 236, 256-267. DOI: 10.1016/j.agee.2016.12.013.

Gerlach, T., 1967. Hillslope troughs for measuring sediment movement. Rev. Geomorphol. Dyn., 17, 173.

Godefroid, S., Koedam, N., 2004. The impact of forest paths upon adjacent vegetation: effects of the path surfacing material on the species composition and soil compaction. Biol. Conserv., 119, 405-419. DOI:10.1016/j.biocon.2004.01.003.

Hacisalihoglu, S., 2007. Determination of soil erosion in a steep hill slope with different land-use types: a case study in Mertesdorf (Ruwertal/Germany). J. Environ. Biol. Acad. Environ. Biol. India, 28, 433-438.

Hänsel, P., Schindewolf, M., Eltner, A., Kaiser, A., Schmidt, J., 2016. Feasibility of high-resolution soil erosion measurements by means of rainfall simulations and SfM photogrammetry. Hydrology, 3, 38. DOI: 10.3390/hydrology3040038.

Hewlett, J.D., Hibbert, A.R., 1967. Factors affecting the response of small watersheds to precipitation in humid areas. In: Sopper, W.E., Lull, H.W. (Ed.): Forest Hydrology. Pergamon Press, New York, pp. 275-290.

Hosseini, M., Rajabi Agereh, S., Khaledian, Y., Jafarzadeh Zoghalchali, H., Brevik, E.C., Movahedi Naeini, S.A.R., 2017. Comparison of multiple statistical techniques to predict soil phosphorus. Appl. Soil Ecol., 114, 123-131. DOI: 10.1016/j.apsoil.2017.02.011.

Iserloh, T., Fister, W., Seeger, M., Willger, H., Ries, J.B., 2012. A small portable rainfall simulator for reproducible experiments on soil erosion. Soil Tillage Res., 124, 131-137. DOI: 10.1016/j.still.2012.05.016.

IUSS Working Group WRB, 2014. World Reference Base for Soil Resources 2014, World Soil Resources Report. FAO, Rome.

Keesstra, S.D., 2007. Impact of natural reforestation on floodplain sedimentation in the Dragonja basin, SW Slovenia. Earth Surface Processes and Landforms, 32, 1, 49-65. DOI: 10.1002/esp.1360.

Keesstra, S., Geissen, V., Mosse, K., Piiranen, S., Scudiero, E., Leistra, M., van Schaik, L., 2012. Soil as a filter for groundwater quality. Curr. Opin. Environ. Sustain., 4, 507516. DOI:10.1016/j.cosust.2012.10.007.

Lasanta, T., 1985. Aportación al estudio de la erosión hídrica en campos cultivados de la Rioja, Ciencias de la Tierra. Instituto de Estudios Riojanos, Logroño (Spain).

Martínez-Casasnovas, J.A., Ramos, M.C., García-Hernández, D., 2009. Effects of land-use changes in vegetation cover and sidewall erosion in a gully head of the Penedès region (northeast Spain). Earth Surf. Process. Landf., 34, 19271937. DOI: 10.1002/esp.1870.

Marzen, M., Iserloh, T., Casper, M.C., Ries, J.B., 2015. Quantification of particle detachment by rain splash and winddriven rain splash. Catena, 127, 135-141. DOI: 10.1016/j.catena.2014.12.023.

Masselink, R.J.H., Keesstra, S.D., Temme, A.J.A.M., Seeger, M., Giménez, R., Casalí, J., 2016. Modelling discharge and sediment yield at catchment scale using connectivity components. Land Degrad. Dev., 27, 4, 933-945. DOI: 10.1002/ldr.2512.

Mathews, A.J., Jensen, J.L.R., 2013. Visualizing and quantifying vineyard canopy LAI using an unmanned aerial vehicle 
(UAV) collected high density structure from motion point cloud. Remote Sens., 5, 2164-2183. DOI: 10.3390/rs5052164.

Mohajerani, H., Kholghi, M., Mosaedi, A., Farmani, R., Sadoddin, A., Casper, M., 2017. Application of bayesian decision networks for groundwater resources management under the conditions of high uncertainty and data scarcity. Water Resour. Manag., 1-21. DOI:10.1007/s11269-017-1616-7.

Nasri, B., Fouché, O., Torri, D., 2015. Coupling published pedotransfer functions for the estimation of bulk density and saturated hydraulic conductivity in stony soils. Catena, 131, 99-108. DOI: 10.1016/j.catena.2015.03.018.

Nearing, M.A., Govers, G., Norton, L.D., 1999. Variability in soil erosion data from replicated plots. Soil Sci. Soc. Am. J., 63, 1829-1835.

Novara, A., Gristina, L., Saladino, S.S., Santoro, A., Cerdà, A., 2011. Soil erosion assessment on tillage and alternative soil managements in a Sicilian vineyard. Soil Tillage Res., 117, 140-147. DOI: 10.1016/j.still.2011.09.007.

Novara, A., Cerdà, A., Dazzi, C., Lo Papa, G., Santoro, A., Gristina, L., 2015. Effectiveness of carbon isotopic signature for estimating soil erosion and deposition rates in Sicilian vineyards. Soil Tillage Res., 152, 1-7. DOI: 10.1016/j.still.2015.03.010.

Paroissien, J.-B., Lagacherie, P., Le Bissonnais, Y., 2010. A regional-scale study of multi-decennial erosion of vineyard fields using vine-stock unearthing-burying measurements. Catena, 82, 159-168. DOI: 10.1016/j.catena.2010.06.002.

Prosdocimi, M., Jordán, A., Tarolli, P., Keesstra, S., Novara, A., Cerdà, A., 2016. The immediate effectiveness of barley straw mulch in reducing soil erodibility and surface runoff generation in Mediterranean vineyards. Sci. Total Environ., 547, 323-330. DOI: 10.1016/j.scitotenv.2015.12.076.

Pulido-Fernández, M., Schnabel, S., Lavado-Contador, J.F., Miralles Mellado, I., Ortega Pérez, R., 2013. Soil organic matter of Iberian open woodland rangelands as influenced by vegetation cover and land management. Catena, 109, 1324. DOI: 10.1016/j.catena.2013.05.002.

Quinn, N.W., Morgan, R.P.C., Smith, A.J., 1980. Simulation of soil erosion induced by human trampling. J. Environ. Manage., 10, 155-165.

Ramos, M.C., Martínez-Casasnovas, J.A., 2006. Impact of land levelling on soil moisture and runoff variability in vineyards under different rainfall distributions in a Mediterranean climate and its influence on crop productivity. J. Hydrol., 321, 131-146. DOI: 10.1016/j.jhydrol.2005.07.055.

Ramos, M.C., Nacci, S., Pla, I., 2000. Soil sealing and its influence on erosion rates for some soils in the Mediterranean area. Soil Sci., 165, 398-403.

Richter, G., 1980. On the soil erosion problem in the temperate humid area of Central Europe. GeoJournal, 4, 279-287.

Ries, J.B., Seeger, M., Iserloh, T., Wistorf, S., Fister, W., 2009. Calibration of simulated rainfall characteristics for the study of soil erosion on agricultural land. Soil Tillage Res. 106, 109-116. DOI: 10.1016/j.still.2009.07.005.

Rodrigo Comino, J., Brings, C., Lassu, T., Iserloh, T., Senciales, J., Martínez Murillo, J., Ruiz Sinoga, J., Seeger, M., Ries, J., 2015a. Rainfall and human activity impacts on soil losses and rill erosion in vineyards (Ruwer Valley, Germany). Solid Earth, 6, 823-837. DOI: 10.5194/se-6-823-2015.
Rodrigo Comino, J., Lassu, T., González, J.M.S., Sinoga, J.D.R., Seeger, K.M., Ries, J.B., 2015b. Estudio de procesos geomorfodinámicos en campos cultivados de viñedos sobre laderas en pendientes en el valle del Ruwer (Alemania). Cuad. Geográficos, 54, 6-26.

Rodrigo Comino, J., Quiquerez, A., Follain, S., Raclot, D., Le Bissonnais, Y., Casalí, J., Giménez, R., Cerdà, A., Keesstra, S.D., Brevik, E.C., Pereira, P., Senciales, J.M., Seeger, M., Ruiz Sinoga, J.D., Ries, J.B., 2016. Soil erosion in sloping vineyards assessed by using botanical indicators and sediment collectors in the Ruwer-Mosel valley. Agric. Ecosyst. Environ., 233, 158-170. DOI: 10.1016/j.agee.2016.09.009.

Ruiz-Colmenero, M., Bienes, R., Eldridge, D.J., Marques, M.J., 2013. Vegetation cover reduces erosion and enhances soil organic carbon in a vineyard in the central Spain. Catena, 104, 153-160. DOI: 10.1016/j.catena.2012.11.007.

Ruiz-Colmenero, M., Bienes, R., Marques, M.J., 2011. Soil and water conservation dilemmas associated with the use of green cover in steep vineyards. Soil Tillage Res., 117, 211223. DOI: 10.1016/j.still.2011.10.004.

Sadeghi, S.H., Kiani Harchegani, M., Asadi, H., 2017. Variability of particle size distributions of upward/downward splashed materials in different rainfall intensities and slopes. Geoderma, 290, 100-106. DOI: 10.1016/j.geoderma.2016.12.007.

Salomé, C., Coll, P., Lardo, E., Metay, A., Villenave, C., Marsden, C., Blanchart, E., Hinsinger, P., Le Cadre, E., 2016. The soil quality concept as a framework to assess management practices in vulnerable agroecosystems: A case study in Mediterranean vineyards. Ecol. Indic., 61, Part 2, 456-465. DOI: 10.1016/j.ecolind.2015.09.047.

Sofia, G., Tarolli, P., 2017. Hydrological response to $\sim 30$ years of agricultural surface water management. Land, 6, 3. DOI: 10.3390/land6010003.

Tarolli, P., Sofia, G., Calligaro, S., Prosdocimi, M., Preti, F., Dalla Fontana, G., 2015. Vineyards in terraced landscapes: new opportunities from Lidar Data. Land Degrad. Dev., 26, 92-102. DOI: 10.1002/ldr.2311.

Taylor, J.A., Coulouma, G., Lagacherie, P., Tisseyre, B., 2009. Mapping soil units within a vineyard using statistics associated with high-resolution apparent soil electrical conductivity data and factorial discriminant analysis. Geoderma, 153, 278-284. DOI: 10.1016/j.geoderma.2009.08.014.

Tibor, M.A., Brevik, E.C., 2013. Anthropogenic impacts on campsite soils at Strawberry Lake, North Dakota. Soil Horiz., 54. DOI: 10.2136/sh13-06-0016.

Urhausen, S., Brienen, S., Kapala, A., Simmer, C., 2011. Climatic conditions and their impact on viticulture in the Upper Moselle region. Clim. Change, 109, 349-373. DOI: 10.1007/s10584-011-0059-z.

Williams, M., Brevik, E.C., 2010. Effect of traffic rate and type on soil compaction in sandy South Georgia soils. Soil Horiz., 51. DOI: 10.2136/sh2010.3.0088.

Received 1 December 2016 Accepted 30 January 2017 